\title{
EVALUASI KEPUASAN PENGGUNA TERHADAP SISTEM INFORMASI KEUANGAN DI SEKOLAH
}

\author{
Annisa Gatri Zakinah ${ }^{\mathrm{a}, 1}$

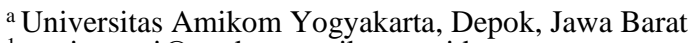 \\ 1 annisagatri@students.amikom.ac.id
}

\section{ARTICLE INFO}

Keywords

Aplikasi, UTAUT, EUCS

\begin{abstract}
Teknologi informasi dapat meingkatkan kinerja suatu organisasi, tetapi kurangnya penerimaan atau kepuasan pengguna pada suatu sistem dapat menjadi faktor penghambat. Dalam dunia pendidikan, hal-hal lain seperti pembiayaan juga ikut berperan aktif dalam meningkatkan pelayanan dan kinerja organisasi. Dibutuhkan sistem yang baik agar dapat menyediakan sistem pembayaran yang mudah, efektif, dan efisien. Salah satu yayasan pendidikan yang menaungi unit KB/TK, SD, SMP, dan SMA telah mempunyai sistem aplikasi ESCOLA yang khusus menangani pengelolaan keuangan. Supaya tujuan yayasan dapat tercapai, diperlukan evaluasi kepuasan pengguna terhadap aplikasi. Oleh karena itu, penelitian ini menggunakan metode UTAUT dan EUCS untuk mengukur tingkat kepuasan pengguna. Hasilnya, 68,8\% pengguna menyatakan puas dengan adanya aplikasi ESCOLA. Namun, pengembangan tetap diharapkan oleh pengguna, khususnya dalam hal integrasi dengan aplikasi pendukung lainnya.
\end{abstract}

\section{Pendahuluan}

Teknologi informasi merupakan bagian yang tidak dapat dipisahkan dalam kehidupan manusia saat ini. Teknologi yang terus berkembang harus diiringi dengan kemampuan manusia dalam penggunaannya secara efektif dan efisien [1]. Faktor yang menentukan kesuksesan suatu teknologi adalah penerimaan pengguna terhadap teknologi tersebut [2]. Oleh karena itu, penerimaan pengguna terhadap sistem dapat menjadi faktor penghambat bagi peningkatan kinerja suatu organisasi. Dalam hal ini, teknologi dapat berupa aplikasi maupun sistem informasi dan lingkup organisasi tidak terkecuali di lingkungan pendidikan.

Pelayanan dalam dunia pendidikan tidak hanya dalam hal belajar mengajar, tapi juga segala sesuatu pendukungnya, salah satunya adalah faktor pembiayaan. Kemudahan dalam sistem pembayaran sekolah menjadi hal penting dalam menunjang proses pembelajaran, khususnya pada sekolah swasta. Sistem pembayaran yang mudah dapat menjadi nilai tambah bagi kualitas pelayanan dari sekolah kepada orang tua peserta didik. Tidak hanya itu, sistem pembayaran yang sudah terintegrasi juga dapat menigkatkan kinerja karyawan secara efektif dan efisien. Pembayaran yang mudah dan proses konfirmasi yang cepat membutuhkan suatu sistem informasi real-time di mana memberi kemudahan untuk diakses kapan saja.

Aplikasi ESCOLA merupakan salah satu aplikasi yang dibuat dan diterapkan di salah satu yayasan pendidikan di Depok, Jawa Barat. Aplikasi ini berfungsi untuk pengelolaan keuangan di tiap unit, KB/TK, SD, SMP, dan SMA. Pengguna ESCOLA adalah seluruh admin keuangan di tiap unit yayasan pendidikan. Agar tujuan organisasi dalam meningkatkan kinerja dan pelayanan terbaik dapat terwujud, diperlukan penerimaan pengguna terhadap sistem. Penerimaan pengguna terhadap sistem inilah yang akan menjadi tolok ukur kesuksesan suatu sistem. Oleh karena itu, perlu adanya pengukuran terhadap tingat penerimaan pengguna terhadap aplikasi ESCOLA. Hasil dari pengukuran tersebut dapat dianalisis dan ditentukan seberapa sukses implementasi aplikasi ESCOLA. 


\section{Metodologi Penelitian}

Metode deskriptif kuantitatif digunakan untuk menentukan seberapa tinggi nilai kepuasan pengguna terhadap sistem. Model yang digunakan dalam penelitian ini adalah penggabungan metode Unified Theory of Acceptance and Use of Technology (UTAUT) dan End-User Computing Satisfaction (EUCS). Metode UTAUT mempunyai fokus untuk menentukan tingkat penerimaan sistem dan penggunaan teknologi di kalangan pengguna [3]. Metode EUCS adalah sebagai pelengkap dari kekurangan yang ada pada metode UTAUT, yaitu berfokus pada kepuasan pengguna akhir terhadap sistem [3]. Pada akhirnya penelitian ini akan mendapatkan hasil berupa tingkat penggunaan dan kepuasan pengguna terhadap sistem yang digunakan.

\subsection{UTAUT}

Model UTAUT dikembangkan oleh Venkatesh et.al (2003) [4]. Model ini merupakan gabungan dari 8 model dan teori yang dominan, di antaranya Theory of Reasoned Action (TRA), Technology Acceptance Model (TAM), The Motivational Model (MM), Theory of Planned Behavior (TPB), Planned Behaviour/Technology Acceptance Model (C-TPBTAM), Model of PC Utilization (MPCU), Innovation Diffusion Theory (IDT), dan Social Cognitive Theory (SCT). Model ini berkontribusi antara $17 \%$ dan 53\% dalam menentukan niat pengguna untuk menggunakan sistem [5].

Penelitian ini menggunakan 5 konstruk yang ada dalam model UTAUT untuk menilai kepuasan pengguna terhadap sistem. Kerangka model UTAUT ditampilkan pada gambar 1. di mana 5 konstruk, yaitu Performance Expectancy, Effort Expectancy, Social Influence, Facilitating Conditions, dan Behavioral Intentions menjadi penentu atas penerimaan sistem oleh pengguna yang dapat juga sebagai penggambaran atas kepuasan pengguna terhadap sistem.

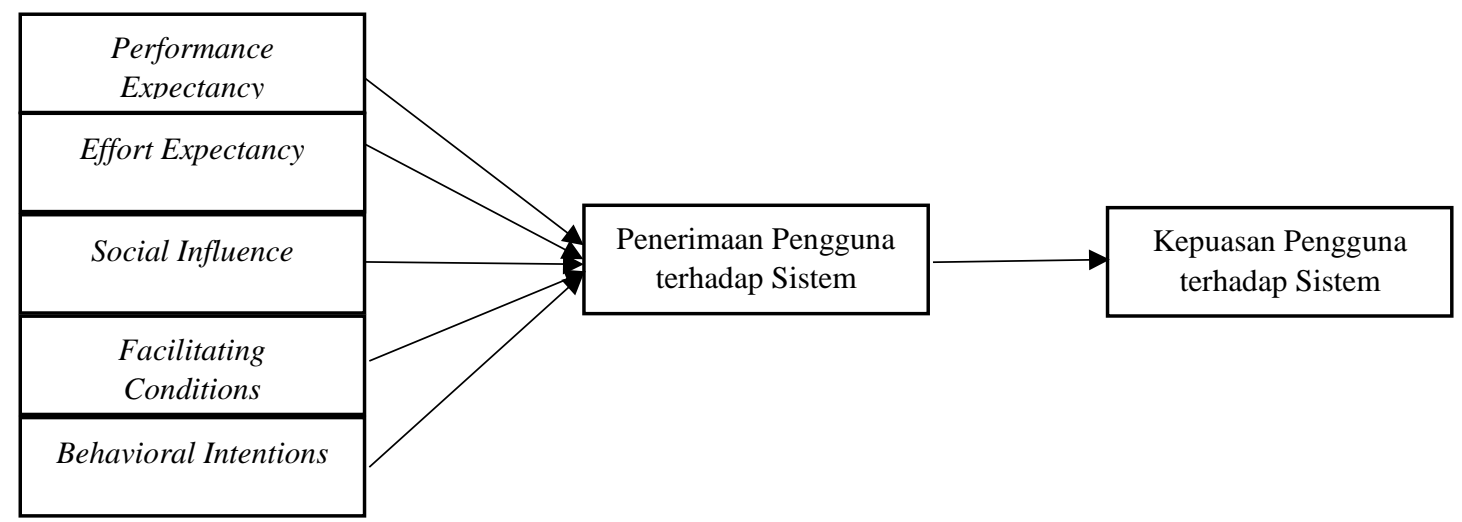

Gambar 1. Kerangka Model UTAUT

Sedangkan instrumen pernyataan hasil penjabaran dari kelima konstruk tersebut seperti yang tercantum pada tabel 2.

\section{Tabel 2. Instrumen UTAUT}

PE1. ESCOLA dapat membantu Saya dalam pengelolaan keuangan

PE2. Menggunakan ESCOLA memungkinkan Saya mengelola keuangan dengan lebih cepat

Performance Expectancy

PE3. Menurut saya Aplikasi ESCOLA memudahkan saya dalam bekerja

PE4. Menggunakan Aplikasi ESCOLA meningkatkan efektifitas saya dalam bekerja

PE5. Aplikasi ESCOLA dapat meningkatkan kualitas dalam bekerja

Effort Expectancy

EE1. Menurut saya Aplikasi ESCOLA mudah digunakan

EE2. Interaksi dalam ESCOLA jelas dan mudah dimengerti 


\begin{tabular}{|c|c|}
\hline & $\begin{array}{l}\text { EE3. Mudah bagi Saya untuk mempelajari penggunaan ESCOLA } \\
\text { EE4. Mudah bagi saya mengoperasikan fitur-fitur yang ada di Aplikasi ESCOLA }\end{array}$ \\
\hline \multirow{4}{*}{ Social Influence } & SI1. Secara umum lingkungan saya menggunakan Aplikasi ESCOLA \\
\hline & SI2. Pimpinan mengharuskan Saya menggunakan aplikasi ESCOLA \\
\hline & $\begin{array}{l}\text { SI3. Dengan adanya aplikasi ESCOLA membuat saya menjadi lebih percaya diri } \\
\text { dalam mengelola keuangan }\end{array}$ \\
\hline & SI4. Pimpinan menyarankan saya untuk menggunakan aplikasi ESCOLA \\
\hline \multirow{5}{*}{ Facilitating Conditions } & $\begin{array}{l}\text { FC1. Saya memiliki pengetahuan yang diperlukan untuk menggunakan Aplikasi } \\
\text { ESCOLA }\end{array}$ \\
\hline & $\begin{array}{l}\text { FC2. Saya bisa mendapatkan bantuan dari orang lain ketika mengalami kesulitan } \\
\text { menggunakan ESCOLA }\end{array}$ \\
\hline & $\begin{array}{l}\text { FC3. Saya memiliki sumber daya yang diperlukan (misal: smartphone, PC, dll) } \\
\text { untuk menggunakan ESCOLA }\end{array}$ \\
\hline & FC4. Saya mendapatkan panduan penggunaan ESCOLA \\
\hline & $\begin{array}{l}\text { FC5. Tersedia fitur khusus yang membantu saya jika mengalami kesulitan } \\
\text { menggunakan Aplikasi ESCOLA }\end{array}$ \\
\hline \multirow{4}{*}{ Behavioral Intentions } & BI1. Saya selalu menggunakan Aplikasi ESCOLA dalam pekerjaan \\
\hline & BI2. Saya senang menggunakan Aplikasi ESCOLA dalam pekerjaan \\
\hline & BI3. Saya berniat untuk seterusnya menggunakan Aplikasi ESCOLA \\
\hline & $\begin{array}{l}\text { BI4. Saya rasa menggunakan ESCOLA menjadi langkah yang tepat dalam } \\
\text { pengelolaan keuangan }\end{array}$ \\
\hline
\end{tabular}

\subsection{EUCS}

Model EUCS yang digunakan pada penelitian ini adalah konstruksi 5 dimensi yang dikemukakan oleh Doll and Torzadeh (1988) [6]. Model ini bertujuan untuk mengetahui tingkat kepuasan masingmasing individu end-user terhadap kecepatan operasional sistem [7]. Kelima dimensi tersebut adalah content, accuracy, format, ease of use, dan timeliness merupakan penentu kepuasan pengguna akhir terhadap sistem seperti yang terlihat pada gambar 2 .

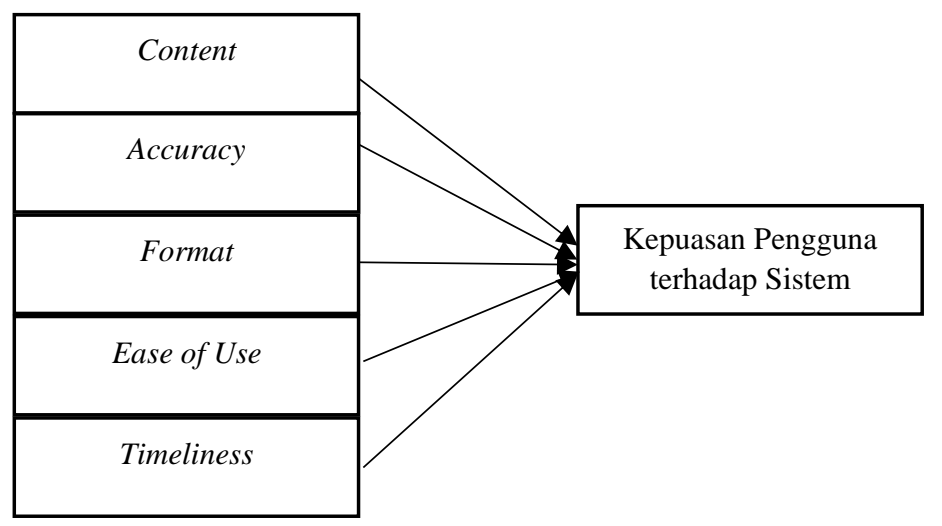

Gambar 1. Kerangka Model EUCS

Pada tabel 2. menampilkan daftar instrumen yang akan digunakan untuk menilai kepuasan pengguna akhir kepada responden.

Tabel 2. Instrumen EUCS

\begin{tabular}{ll}
\hline Content & C1. Aplikasi ESCOLA memberikan informasi tepat yang Saya butuhkan \\
& C2. Konten informasi yang ada memenuhi kebutuhan Saya \\
& C3. Aplikasi ESCOLA menyediakan laporan yang sesuai dengan kebutuhan Saya \\
& C4. ESCOLA menyediakan informasi yang cukup \\
\hline Accuracy & A1. Aplikasi ESCOLA akurat \\
& A2. Saya puas dengan keakuratan Aplikasi ESCOLA \\
\hline Format & F1. Menurut Saya output disajikan dalam format yang berguna \\
\hline
\end{tabular}




\begin{tabular}{ll}
\hline & F2. Informasi yang diberikan Aplikasi ESCOLA jelas \\
\hline Ease of Use & E1. Aplikasi Escola ramah pengguna \\
& E2. Aplikasi ESCOLA mudah digunakan \\
\hline Timeliness & T1. Saya bisa mendapatkan informasi yang dibutuhkan tepat waktu \\
& T2. Aplikasi ESCOLA memberikan informasi terkini \\
\hline
\end{tabular}

\subsection{Pengumpulan Data}

Penelitian ini menggunakan kuesioner sebagai teknik pengumpulan data. Kuesioner berisi instrumen pernyataan dari model UTAUT dan EUCS yang penggambaran jawabannya menggunakan skala likert. Penggunaan skala likert dapat memberikan dampak konstruk bagi kepuasan pengguna terhadap sistem secara keseluruhan [7].

Data didapat dari 8 responden yang bekerja di bidang keuangan dan menggunakan aplikasi ESCOLA. Responden berdasarkan kategori jenis kelamin, sebanyak 87,5\% keuangan dikelola oleh perempuan seperti yang ditampilkan pada tabel 3 .

Tabel 3. Responden Kategori Jenis Kelamin

\begin{tabular}{ccc}
\hline Jenis Kelamin & Frekuensi & Persentase \\
\hline Laki-Laki & 1 & $12,5 \%$ \\
\hline Perempuan & 7 & $87,5 \%$ \\
\hline Total & 8 & $100 \%$ \\
\hline
\end{tabular}

Berdasarkan kategori tingkat pendidikan terakhir, sebanyak 66,8\% responden merupakan lulusan S1 dalam bidang komputer dan keuangan seperti yang tercantum pada tabel 4.

Tabel 4. Responden Kategori Tingkat Pendidikan Akhir

\begin{tabular}{ccc}
\hline Tingkat Pendidikan Akhir & Frekuensi & Persentase \\
\hline S1 Jurusan Komputer.Keuangan & 4 & $50 \%$ \\
\hline S1 Jurusan Non-Komputer.Keuangan & 3 & $37,5 \%$ \\
\hline D3 Jurusan Komputer/Keuangan & 1 & $12,5 \%$ \\
\hline Total & 8 & $100 \%$ \\
\hline
\end{tabular}

Sedangkan berdasarkan kategori usia, 62,5\% dari semua responden berada pada rentang usia 26-40 tahun seperti yang tercantum pada tebel 5 , artinya sebagian besar pengguna aplikasi keuangan adalah generasi milenial di mana mereka termasuk dalam kategori mudah dalam mengoperasikan aplikasi.

Tabel 5. Responden Kategori Usia

\begin{tabular}{ccc}
\hline Usia & Frekuensi & Persentase \\
\hline $26-40$ tahun & 5 & $62,5 \%$ \\
\hline $41-55$ tahun & 3 & $37,5 \%$ \\
\hline Total & 8 & $100 \%$ \\
\hline
\end{tabular}

Hasil data yang didapat dari kuesioner akan dilakukan uji validitas dan uji reliabilitas sebelum diolah. Hal ini dilakukan untuk mengetahui seberapa reliabel data tersebut. Hanya data yang valid dan reliabel yang dapat digunakan dalam penelitian. Setelah data dilakukan uji validitas dan uji reliabilitas, data akan dianalisis untuk mengetahui tingkat kepuasan pengguna dalam setiap variabel dan secara keseluruhan. Teori Kaplan dan Norton menyatakan bahwa Rata-Rata Kepuasan merupakan hasil bagi antara Jumlah Skor Kuesioner dengan Jumlah butir Kuesioner dikalikan dengan jumlah responden seperti tercantum pada persamaan 1 yang digunakan dalam penelitian ini [8].

$$
\mathrm{RK}=\frac{J S K}{J K}
$$


Hasil dari RK diimplementasikan ke dalam tabel Rata-Rata Kepuasan dari Kaplan dan Norton [8] seperti yang tercantum pada tabel 6 untuk mengetahui tingkat kepuasan pengguna terhadap sistem.

Tabel 6. Rata-Rata Kepuasan dari Kaplan dan Norton

\begin{tabular}{cc}
\hline Rentang Nilai & Informasi \\
\hline $1,00-1,79$ & Sangat Tidak Puas \\
\hline $1,80-2,59$ & Tidak Puas \\
\hline $2,60-3,39$ & Ragu-Ragu \\
\hline $3,40-4,91$ & Puas \\
\hline $4,92-5,00$ & Sangat Puas \\
\hline
\end{tabular}

\section{Hasil dan Pembahasan}

Sebelum melakukan pengolahan data, terlebih dahulu data diuji validitas dan reliabilitasnya untuk mengetahui apakah data yang didapat dari responden valid dan dapat digunakan atau tidak untuk penelitian. Pada tabel 7. ditampilkan hasil validitas instrumen pertanyaan.

Tabel 7. Hasil Validitas Instrumen

\begin{tabular}{|c|c|c|c|}
\hline Pertanyaan ke- & r hitung & $r$ tabel & Keputusan \\
\hline PE1 & 0.7579 & 0.707 & Valid \\
\hline PE2 & 0.9372 & 0.707 & Valid \\
\hline PE3 & 0.9372 & 0.707 & Valid \\
\hline PE4 & 0.7579 & 0.707 & Valid \\
\hline PE5 & 0.8752 & 0.707 & Valid \\
\hline EE1 & 0.7454 & 0.707 & Valid \\
\hline EE2 & 0.9333 & 0.707 & Valid \\
\hline EE3 & 0.8614 & 0.707 & Valid \\
\hline EE4 & 0.9759 & 0.707 & Valid \\
\hline SI1 & 0.7577 & 0.707 & Valid \\
\hline SI2 & 0.8705 & 0.707 & Valid \\
\hline SI3 & 0.6629 & 0.707 & Tidak Valid \\
\hline SI4 & 0.8705 & 0.707 & Valid \\
\hline $\mathrm{FC} 1$ & 0.9191 & 0.707 & Valid \\
\hline $\mathrm{FC} 2$ & 0.9649 & 0.707 & Valid \\
\hline FC3 & 0.9649 & 0.707 & Valid \\
\hline $\mathrm{FC} 4$ & 0.9649 & 0.707 & Valid \\
\hline FC5 & 0.9518 & 0.707 & Valid \\
\hline BI1 & 0.7184 & 0.707 & Valid \\
\hline BI2 & 0.8825 & 0.707 & Valid \\
\hline $\mathrm{BI} 3$ & 0.8980 & 0.707 & Valid \\
\hline BI4 & 0.8825 & 0.707 & Valid \\
\hline $\mathrm{C} 1$ & 0.9686 & 0.707 & Valid \\
\hline $\mathrm{C} 2$ & 0.9686 & 0.707 & Valid \\
\hline $\mathrm{C} 3$ & 0.8220 & 0.707 & Valid \\
\hline $\mathrm{C} 4$ & 0.9686 & 0.707 & Valid \\
\hline $\mathrm{A} 1$ & 1.0000 & 0.707 & Valid \\
\hline $\mathrm{A} 2$ & 1.0000 & 0.707 & Valid \\
\hline
\end{tabular}




\begin{tabular}{cccc}
\hline Pertanyaan ke- & r hitung & r tabel & Keputusan \\
\hline F1 & 0.9333 & 0.707 & Valid \\
\hline F2 & 0.8825 & 0.707 & Valid \\
\hline E1 & 1.0000 & 0.707 & Valid \\
\hline E2 & 1.0000 & 0.707 & Valid \\
\hline T1 & 0.6547 & 0.707 & Tidak Valid \\
\hline T2 & 0.7559 & 0.707 & Valid
\end{tabular}

Berdasarkan hasil validitas instrumen, menunjukkan bahwa terdapat 2 instrumen yang tidak valid, yaitu instumen SI3 pada model UTAUT dan T1 pada model EUCS. Kemudian, instrumen yang valid akan dilakukan uji reliabilitas untuk mengetahui tingkat reliabilitas tiap variabelnya. Berdasarkan hasil reliabilitas yang ditampilkan pada tabel 8., semua variabel memiliki tingkat reliabilitas sangat tinggi sehingga layak digunakan untuk penelitian.

Tabel 8. Hasil Reliabilitas Instrumen

\begin{tabular}{ccc}
\hline Variabel & $\mathbf{r}_{11}$ & Tingkat Reliabilitas \\
\hline Performance Expectancy & 0.89 & sangat tinggi \\
\hline Effort Expectancy & 1.01 & sangat tinggi \\
\hline Social Influence & 1.07 & sangat tinggi \\
\hline Facilitating Conditions & 1.01 & sangat tinggi \\
\hline Behavioral Intentions & 0.94 & sangat tinggi \\
\hline Content & 1.05 & sangat tinggi \\
\hline Accuracy & 1.00 & sangat tinggi \\
\hline Format & 0.77 & tinggi \\
\hline Ease of Use & 1.00 & sangat tinggi \\
\hline Timeliness & 0.86 & sangat tinggi
\end{tabular}

Teori Kaplan dan Norton digunakan untuk menentukan nilai rata-rata kepuasan dari masing-masing variabel [8]. Pada tabel 9. menampilkan hasil analisis variabel performance expectancy di mana responden paling banyak menjawab puas dari 4 pernyataan yang diberikan.

Tabel 9. Hasil Analisis Variabel Performance Expectancy

\begin{tabular}{ccccccc}
\hline \multirow{2}{*}{ Jawaban } & \multicolumn{7}{c}{ Pernyataan } & \multirow{2}{*}{ Jumlah } \\
\cline { 2 - 6 } & PE1 & PE2 & PE3 & PE4 & PE5 & 7 \\
\hline Sangat Puas & 2 & 1 & 1 & 2 & 1 & 32 \\
\hline Puas & 6 & 7 & 7 & 6 & 6 & 1 \\
\hline Cukup Puas & 0 & 0 & 0 & 0 & 1 & 0 \\
\hline Tidak Puas & 0 & 0 & 0 & 0 & 0 & 0 \\
\hline Sangat Tidak Puas & 0 & 0 & 0 & 0 & 0 & \\
\hline
\end{tabular}

$$
\begin{gathered}
\mathrm{RK}=\frac{(5 \times 7)+(4 \times 32)+(3 \times 1)+(2 \times 0)+(1 \times 0)}{40} \\
\mathrm{RK}=\frac{35+128+3+0+0}{40} \\
\mathrm{RK}=\frac{166}{40}=4,15
\end{gathered}
$$


Hasil perhitungan variabel performance expectancy dan diintegrasikan ke dalam tabel Rata-Rata Kepuasan dari Kaplan dan Norton menghasilkan nilai 4,15 yang berarti puas. Pada tabel 10. ditampilkan data hasil analisis variabel effort expectancy.

Tabel 10. Hasil Analisis Variabel Effort Expectancy

\begin{tabular}{|c|c|c|c|c|c|}
\hline \multirow{2}{*}{ Jawaban } & \multicolumn{4}{|c|}{ Pernyataan } & \multirow{2}{*}{ Jumlah } \\
\hline & $E E 1$ & $E E 2$ & EE3 & $E E 4$ & \\
\hline Sangat Puas & 2 & 3 & 2 & 3 & 10 \\
\hline Puas & 6 & 5 & 5 & 4 & 20 \\
\hline Cukup Puas & 0 & 0 & 1 & 1 & 2 \\
\hline Tidak Puas & 0 & 0 & 0 & 0 & 0 \\
\hline Sangat Tidak Puas & 0 & 0 & 0 & 0 & 0 \\
\hline
\end{tabular}

$$
\begin{gathered}
\mathrm{RK}=\frac{(5 \times 10)+(4 \times 20)+(3 \times 2)+(2 \times 0)+(1 \times 0)}{32} \\
\mathrm{RK}=\frac{50+80+6+0+0}{32} \\
\mathrm{RK}=\frac{136}{32}=4,25
\end{gathered}
$$

Berdasarkan hasil perhitungan pada variabel effort expectancy diketahui nilai Rata-Rata Kepuasan sebesar 4,25 yang artinya berada pada level puas. Pada tabel 11. ditampilkan hasil analisis variabel

\begin{tabular}{|c|c|c|c|c|c|}
\hline \multirow{2}{*}{ Jawaban } & \multicolumn{4}{|c|}{ Pernyataan } & \multirow{2}{*}{ Jumlah } \\
\hline & SII & $S I 2$ & $S I 3$ & SI4 & \\
\hline Sangat Puas & 4 & 4 & 2 & 4 & 14 \\
\hline Puas & 3 & 4 & 4 & 4 & 15 \\
\hline Cukup Puas & 1 & 0 & 2 & 0 & 3 \\
\hline Tidak Puas & 0 & 0 & 0 & 0 & 0 \\
\hline Sangat Tidak Puas & 0 & 0 & 0 & 0 & 0 \\
\hline
\end{tabular}
social influence.

Tabel 11. Hasil Analisis Variabel Social Influence

$$
\begin{gathered}
\mathrm{RK}=\frac{(5 \times 14)+(4 \times 15)+(3 \times 3)+(2 \times 0)+(1 \times 0)}{32} \\
\mathrm{RK}=\frac{70+60+9+0+0}{32} \\
\mathrm{RK}=\frac{139}{32}=4,34
\end{gathered}
$$

Berdasarkan hasil perhitungan pada variabel social influence didapatkan hasil Rata-Rata Kepuasan sebesar 4,34 yang artinya berada pada level puas. Pada tabel 12. ditampilkan hasil analisis variabel facilitating conditions.

Tabel 12. Hasil Analisis Variabel Facilitating Conditions

\begin{tabular}{ccccccc}
\hline \multirow{2}{*}{ Jawaban } & \multicolumn{7}{c}{ Pernyataan } & \multirow{2}{*}{ Jumlah } \\
\cline { 2 - 6 } & $\boldsymbol{F C} \mathbf{1}$ & $\boldsymbol{F C} \mathbf{2}$ & $\boldsymbol{F C 3}$ & $\boldsymbol{F C 4}$ & $\boldsymbol{F C 5}$ & \\
\hline Sangat Puas & 2 & 2 & 2 & 2 & 2 & 10 \\
\hline Puas & 4 & 6 & 6 & 6 & 2 & 24 \\
\hline Cukup Puas & 2 & 0 & 0 & 0 & 4 & 6 \\
\hline
\end{tabular}




\begin{tabular}{cllllll}
\hline Tidak Puas & 0 & 0 & 0 & 0 & 0 & 0 \\
\hline Sangat Tidak Puas & 0 & 0 & 0 & 0 & 0 & 0 \\
\hline
\end{tabular}

$$
\begin{gathered}
\mathrm{RK}=\frac{(5 \times 10)+(4 \times 24)+(3 \times 6)+(2 \times 0)+(1 \times 0)}{40} \\
\mathrm{RK}=\frac{50+96+18+0+0}{40} \\
\mathrm{RK}=\frac{164}{40}=4,10
\end{gathered}
$$

Berdasarkan hasil perhitungan, nilai Rata-Rata Kepuasan variabel facilitating conditions sebesar 4,10 di mana nilai tersebut ada pada level puas. Pada tabel 13. menampilkan hasil analisis variabel

\begin{tabular}{|c|c|c|c|c|c|}
\hline \multirow{2}{*}{ Jawaban } & \multicolumn{4}{|c|}{ Pernyataan } & \multirow{2}{*}{ Jumlah } \\
\hline & BII & $B I 2$ & BI3 & BI4 & \\
\hline Sangat Puas & 4 & 1 & 1 & 1 & 7 \\
\hline Puas & 4 & 7 & 6 & 7 & 24 \\
\hline Cukup Puas & 0 & 0 & 1 & 0 & 1 \\
\hline Tidak Puas & 0 & 0 & 0 & 0 & 0 \\
\hline Sangat Tidak Puas & 0 & 0 & 0 & 0 & 0 \\
\hline \multicolumn{6}{|c|}{ 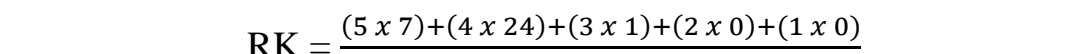 } \\
\hline \multicolumn{6}{|c|}{$\mathrm{Kn}=$} \\
\hline \multicolumn{6}{|c|}{$\mathrm{RK}=\frac{35+96+3+0+0}{2}$} \\
\hline \multicolumn{6}{|c|}{32} \\
\hline \multicolumn{6}{|c|}{$\mathrm{RK}=\frac{134}{32}=4,19$} \\
\hline
\end{tabular}
behavioral intentions.

Tabel 13. Hasil Analisis Variabel Behavioral Intentions

Berdasarkan hasil perhitungan Rata-Rata Kepuasan pada variabel behavioral intentions mendapatkan nilai sebesar 4,19 yang berada pada level puas. Pada tabel 14. menampilkan frekuensi dari seluruh variabel UTAUT.

Tabel 14. Frekuensi Variabel Keseluruhan UTAUT

\begin{tabular}{cccc}
\hline Jawaban & Skala Likert & Frekuensi & Persentase \\
\hline Sangat Puas & 5 & 48 & 27,3 \\
\hline Puas & 4 & 115 & 65,3 \\
\hline Cukup Puas & 3 & 13 & 7,4 \\
\hline Tidak Puas & 2 & 0 & 0 \\
\hline Sangat Tidak Puas & 1 & 0 & 0 \\
\hline Total & & 176 & 100 \\
\hline
\end{tabular}

Frekuensi dari seluruh variabel UTAUT menunjukkan hasil bahwa perolehan persentase jawaban sangat puas sebesar $27,3 \%$, puas $65,3 \%$, cukup puas $7,4 \%$, dan jawaban lainnya sebesar $0 \%$. Hal ini menunjukkan bahwa penelitian menggunakan model instrumen UTAUT menunjukkan bahwa responden puas dengan aplikasi ESCOLA. Kemudian hasil analisis model EUCS dengan variabel content ditampilkan pada tabel 15.

Tabel 15. Hasil Analisis Variabel Content 


\begin{tabular}{|c|c|c|c|c|c|}
\hline \multirow{2}{*}{ Jawaban } & \multicolumn{4}{|c|}{ Pernyataan } & \multirow{2}{*}{ Jumlah } \\
\hline & $C 1$ & $C 2$ & C3 & $C 4$ & \\
\hline Sangat Puas & 1 & 1 & 2 & 1 & 5 \\
\hline Puas & 7 & 7 & 6 & 7 & 27 \\
\hline Cukup Puas & 0 & 0 & 0 & 0 & 0 \\
\hline Tidak Puas & 0 & 0 & 0 & 0 & 0 \\
\hline Sangat Tidak Puas & 0 & 0 & 0 & 0 & 0 \\
\hline
\end{tabular}

$$
\begin{gathered}
\mathrm{RK}=\frac{(5 \times 5)+(4 \times 27)+(3 \times 0)+(2 \times 0)+(1 \times 0)}{32} \\
\mathrm{RK}=\frac{25+108+0+0+0}{32} \\
\mathrm{RK}=\frac{133}{32}=4,16
\end{gathered}
$$

Berdasarkan hasil perhitungan, didapat hasil 4,16 untuk Rata-Rata Kepuasan variabel content yang

\begin{tabular}{|c|c|c|c|}
\hline \multirow{2}{*}{ Jawaban } & \multicolumn{2}{|c|}{ Pernyataan } & \multirow{2}{*}{ Jumlah } \\
\hline & $A 1$ & $A 2$ & \\
\hline Sangat Puas & 1 & 1 & 2 \\
\hline Puas & 5 & 5 & 10 \\
\hline Cukup Puas & 2 & 2 & 4 \\
\hline Tidak Puas & 0 & 0 & 0 \\
\hline Sangat Tidak Puas & 0 & 0 & 0 \\
\hline \multicolumn{4}{|c|}{$\mathrm{RK}=\underline{(5 \times 2)+\left(\begin{array}{lll}4 & x & 10\end{array}\right)+(3 \times 4)+(2 \times 0)+(1 \times 0)}$} \\
\hline \multicolumn{4}{|c|}{$\mathrm{Kn}=\frac{16}{16}$} \\
\hline \multicolumn{4}{|c|}{$\mathrm{RK}=\underline{10+40+12+0+0}$} \\
\hline \multicolumn{4}{|c|}{$\mathrm{KK}=\frac{16}{16}$} \\
\hline \multicolumn{4}{|c|}{$\mathrm{RK}=\frac{139}{16}=3,88$} \\
\hline
\end{tabular}
artinya berada pada level puas. Pada tabel 16. ditampilkan hasil analisis variabel accuracy.

Tabel 16. Hasil Analisis Variabel Accuracy

Berdasarkan hasil perhitungan Rata-Rata Kepuasan variabel accuracy mendapat nilai sebesar 3,88

\begin{tabular}{|c|c|c|c|}
\hline \multirow{2}{*}{ Jawaban } & \multicolumn{2}{|c|}{ Pernyataan } & \multirow{2}{*}{ Jumlah } \\
\hline & $F 1$ & $F 2$ & \\
\hline Sangat Puas & 2 & 1 & 3 \\
\hline Puas & 6 & 7 & 13 \\
\hline Cukup Puas & 0 & 0 & 0 \\
\hline Tidak Puas & 0 & 0 & 0 \\
\hline Sangat Tidak Puas & 0 & 0 & 0 \\
\hline \multicolumn{4}{|c|}{$\mathrm{RK}=\underline{(5 \times 3)+(4 \times 13)+(3 \times 0)+(2 \times 0)+(1 \times 0)}$} \\
\hline \multicolumn{4}{|c|}{$\mathrm{RK}=\frac{15+52+0+0+0}{16}$} \\
\hline
\end{tabular}
yang berada pada level puas. Pada tabel 17. menampilkan hasil analisis variabel format.

Tabel 17. Hasil Analisis Variabel Format 


$$
\mathrm{RK}=\frac{67}{16}=4,19
$$

Berdasarkan hasil perhitungan, nilai Rata-Rata Kepuasan variabel format adalah 4,19 yang berada pada level puas. Pada tabel 18. menampilkan hasil analisis variabel ease of use.

Tabel 18. Hasil Analisis Variabel Ease of Use

\begin{tabular}{cccc}
\hline \multirow{2}{*}{ Jawaban } & \multicolumn{2}{c}{ Pernyataan } & \multirow{2}{*}{ Jumlah } \\
\cline { 2 - 3 } & $\boldsymbol{E} \mathbf{1}$ & $\boldsymbol{E 2}$ & \\
\hline Sangat Puas & 3 & 3 & 6 \\
\hline Puas & 5 & 5 & 10 \\
\hline Cukup Puas & 0 & 0 & 0 \\
\hline Tidak Puas & 0 & 0 & 0 \\
\hline Sangat Tidak Puas & 0 & 0 & 0 \\
\hline
\end{tabular}

$$
\begin{gathered}
\mathrm{RK}=\frac{(5 \times 6)+(4 \times 10)+(3 \times 0)+(2 \times 0)+(1 \times 0)}{16} \\
\mathrm{RK}=\frac{30+40+0+0+0}{16} \\
\mathrm{RK}=\frac{70}{16}=4,38
\end{gathered}
$$

Berdasarkan hasil perhitungan, didapat nilai Rata-Rata Kepuasan variabel ease of use sebesar 4,38 yang artinya level kepuasan ada pada rentang puas. Pada tabel 19. menampilkan hasil analisis variabel timeliness.

Tabel 19. Hasil Analisis Variabel Timeliness

\begin{tabular}{cccc}
\hline \multirow{2}{*}{ Jawaban } & \multicolumn{2}{c}{ Pernyataan } & \multirow{2}{*}{ Jumlah } \\
\cline { 2 - 3 } & $\boldsymbol{T 1}$ & $\boldsymbol{T 2}$ & 3 \\
\hline Sangat Puas & 2 & 1 & 12 \\
\hline Puas & 6 & 6 & 1 \\
\hline Cukup Puas & 0 & 1 & 0 \\
\hline Tidak Puas & 0 & 0 & 0 \\
\hline Sangat Tidak Puas & 0 & 0 & \\
\hline
\end{tabular}

$$
\begin{gathered}
\mathrm{RK}=\frac{(5 \times 3)+(4 \times 12)+(3 \times 1)+(2 \times 0)+(1 \times 0)}{16} \\
\mathrm{RK}=\frac{15+48+3+0+0}{16} \\
\mathrm{RK}=\frac{66}{16}=4,13
\end{gathered}
$$

Berdasarkan hasil perhitungan, didapat nilai Rata-Rata Kepuasan sebesar 4,13 yang artinya berada pada level puas. Kemudian frekuensi seluruh variabel model EUCS ditampilkan pada tabel 20.

Tabel 20. Frekuensi Variabel Keseluruhan EUCS

\begin{tabular}{cccc}
\hline Jawaban & Skala Likert & Frekuensi & Persentase \\
\hline Sangat Puas & 5 & 19 & 19,8 \\
\hline Puas & 4 & 72 & 75 \\
\hline Cukup Puas & 3 & 5 & 5,2 \\
\hline Tidak Puas & 2 & 0 & 0 \\
\hline
\end{tabular}




\begin{tabular}{cccc}
\hline Jawaban & Skala Likert & Frekuensi & Persentase \\
\hline Sangat Tidak Puas & 1 & 0 & 0 \\
\hline Total & & 96 & 100 \\
\hline
\end{tabular}

Frekuensi seluruh variabel dalam instrumen model EUCS menunjukkan hasil yaitu, persentase jawaban responden sangat puas sebesar $19,8 \%$, puas $75 \%$, cukup puas $5,2 \%$, dan jawaban lainnya $0 \%$ karena tidak ada responden yang menjawab. Hal ini menunjukkan bahwa dalam model EUCS, pengguna puas akan aplikasi ESCOLA. Kemudian hasil frekuensi seluruh variabel pada model UTAUT dan model EUCS digabungkan dalam tabel 21. untuk melihat hasil secara keseluruhan.

Tabel 21. Gabungan Frekuensi Variabel UTAUT dan EUCS

\begin{tabular}{cccc}
\hline Jawaban & Skala Likert & Frekuensi & Persentase \\
\hline Sangat Puas & 5 & 67 & 24,6 \\
\hline Puas & 4 & 187 & 68,8 \\
\hline Cukup Puas & 3 & 18 & 6,6 \\
\hline Tidak Puas & 2 & 0 & 0 \\
\hline Sangat Tidak Puas & 1 & 0 & 0 \\
\hline Total & & 272 & 100 \\
\hline
\end{tabular}

Berdasarkan tabel 21., gabungan frekuensi dari seluruh variabel UTAUT dan EUCS menunjukkan hasil persentase sangat puas sebesar $24,6 \%$, puas $68,8 \%$, dan cukup puas $6,6 \%$, sedangkan jawaban tidak puas dan sangat tidak puas $0 \%$ karena tidak mendapatkan respon dari responden. Hal ini menunjukkan bahwa hasil kepuasan pengguna secara keseluruhan ada pada level puas.

\section{Kesimpulan}

Penelitian tingkat kepuasan aplikasi ESCOLA menggunakan metode UTAUT dan EUCS menghasilkan kesimpulan sebagai berikut:

1. Pada metode UTAUT, $65,3 \%$ menyatakan puas dengan adanya aplikasi tersebut. Sisanya menyatakan sangat puas sebanyak $27,3 \%$ dan cukup puas sebanyak $7,4 \%$.

2. Pada metode EUCS, $75 \%$ pengguna menyatakan puas menggunakan aplikasi tersebut. Sisanya sebanyak 19,8\% sangat puas dan 5,2\% menyatakan cukup puas.

3. Hasil gabungan dari kedua metode tersebut menunjukkan persentase tertinggi sebesar $68,8 \%$ pengguna yang menyatakan puas sedangkan $24,6 \%$ sangat puas dan $6,6 \%$ menyatakan cukup puas terhadap aplikasi tersebut.

4. Penggabungan metode UTAUT dan EUCS dalam evaluasi kepuasan pengguna terhadap aplikasi ESCOLA menunjukkan bahwa 68,8\% pengguna telah merasa puas sehingga kesuksesan implementasi aplikasi tersebut juga dinyatakan sukses.

Walapun implementasi aplikasi ini telah mencapai kesuksesan, tapi tetap harus adanya peningkatan baik itu dari sisi fitur, keamanan, maupun integrasi dengan aplikasi lainnya. Jadi, pengembangan aplikasi harus terus dilakukan agar pengguna dapat menggunakan aplikasi ini secara terus menerus untuk meningkatkan kinerjanya. 


\section{Daftar Pustaka}

[1] O. J. F. Wassalam, R. Umar, and A. Yudhana, "Pengukuran Kesuksesan Implementasi E-Learning dengan Metode TAM dan UTAUT," J. Edukasi dan Penelit. Inform., vol. 6, no. 1, 2020, doi: 10.26418/jp.v6i1.37938.

[2] H. Pamugar, W. W. Winarno, and W. Najib, "Model Evaluasi Kesuksesan dan Penerimaan Sistem Informasi E-Learning pada Lembaga Diklat Pemerintah,” Sci. J. Informatics, vol. 1, no. 1, 2014, doi: 10.15294/sji.v1i1.3638.

[3] L. Chrisantyo, Y. Lukito, and A. R. Chrismanto, "PELATIHAN GOOGLE SUITE TERHADAP DEWAN PAROKI KLATEN DAN PENGUKURAN TINGKAT PENERIMAAN TEKNOLOGINYA," SHARE “SHaring - Action - REflection,” vol. 6, no. 1, 2020, doi: 10.9744/share.6.1.1-6.

[4] V. Venkatesh, M. G. Morris, G. B. Davis, and F. D. Davis, "User acceptance of information technology: Toward a unified view," MIS Q. Manag. Inf. Syst., vol. 27, no. 3, 2003, doi: 10.2307/30036540.

[5] M. D. Williams, N. P. Rana, and Y. K. Dwivedi, "The unified theory of acceptance and use of technology (UTAUT): A literature review," Journal of Enterprise Information Management, vol. 28, no. 3. 2015, doi: 10.1108/JEIM-09-2014-0088.

[6] W. J. Doll and G. Torkzadeh, “The Measurement of End-User Computing Satisfaction,” MIS Q., vol. 12, no. 2, pp. 259-274, Aug. 1988, doi: 10.2307/248851.

[7] W. W. Chin and M. K. O. Lee, "A proposed model and measurement instrument for the formation of IS satisfaction: the case of end-user computing satisfaction," in ICIS, 2000, vol. Brisbane,.

[8] W. A. Putera and I. M. Candiasa, "Analysis of e-learning user satisfaction itb stikom bali using end user computing satisfaction (eucs) method," in Journal of Physics: Conference Series, 2021, vol. 1810, no. 1, doi: 10.1088/1742-6596/1810/1/012017. 